\title{
PRELIMINARY EVALUATION OF In vitro SECONDARY METABOLITES OF Sclerotium cepivorum, THE CAUSAL AGENT OF ONION WHITE ROT El-Sheshtawi, Mohamed ${ }^{1}$; Mona G. Zaghloul ${ }^{2}$; E. A. Elsherbiny ${ }^{1}$ and Amany S. M.Saad ${ }^{1}$ \\ ${ }^{1}$ Plant Pathology Department, Faculty of Agriculture, Mansoura University, El-Mansoura 35516, Egypt \\ ${ }^{2}$ Pharmacognosy Department, Faculty of Pharmacy, Mansoura University, EI-Mansoura 35516, Egypt
}

\begin{abstract}
Culture filtrates and organic solvent extracts of Sclerotium cepivorum liquid cultures were evaluated for their antifungal activities against the same fungus. Filtrates at $50 \%$ taken from 30 to 45 -day-old cultures have reduced $S$. cepivorum growth by $51.9 \%$. This treatment has also caused a reduction in the number of sclerotia by $98.6 \%$. No sclerotial germination was observed on the media amended with the culture filtrates at all concentrations tested (10, 25 and 50\%),.Among all organic solvent extracts, methanol extract was the strongest growth inhibitor against the fungal pathogen; it inhibited S. cepivorum growth by 82.2, 93.3, and $93.6 \%$ when used at concentrations of 400,800, and $1200 \mathrm{ppm}$, respectively. At the same concentrations, ethyl acetate extract exhibited high inhibition to the fungal growth i.e., 85.56, 88.89, and $90.56 \%$, respectively, while chloroform extract was the least effective in this regard causing $71.11 \%$ mycelial growth inhibition when used at concentrations of either 800 or 1200 ppm. All organic-solvent extracts completely suppressed the formation and germination of sclerotia at all concentrations. Further studies are needed to isolate different bioactive compounds from secondary metabolites of S. cepivorum.

Kewwords: Antifungal activity, Sclerotium cepivorum, secondary metabolites,
\end{abstract} biological control.

\section{INTRODUCTION}

Onion (Allium cepa L.) has beenan important cash crop in Egypt with a special significane for export. However, in recent years, onion production has been significantly reduced mainly in the Upper Egypt due to the spread of white rot disease caused by Sclerotium cepivorum Berk. It has become a recurrent problem in major onion production areas all over the world (Mengistu and Seid, 1993; Mengistu, 1994). The disease is prevalent in many Allium growing regions worldwide and causes serious economic losses in onion and garlic crops (Crowe et. al., 1980; Perez et. al., 1994; Andrea et. al., 1996 and Pinto et. al., 1998). The pathogen, S. cepivorum, produces numerous small-size sclerotia, which aid in its survival and form a primary source of inoculum. On germination, the sclerotia produce mycelium, which penetrates the root epidermis and invades the cortical parenchyma both intra and intercellulary causing extensive tissue degradation (Abd-El-Raziket. al., 1973). Infected plants suffer from water stress and usually die prematurely (Entwistle, 1990b). 


\section{El-Sheshtawi, Mohamed et al.}

Management of soil-borne diseases especially those that produce sclerotia is very difficult and thus an integrated strategy should be approached. Crop rotation with non host crops (Banks and Edgington, 1989), soil solarization (Porter and Merriman, 1983 and Melero-Varaet. al., 2000), biological control agents (Harrison and Stewart, 1988; Kay and Stewart, 1994b; and Gerlaghet. al., 1996), sclerotia germination stimulants (ColeySmith and Parfitt, 1986), and composted onion waste (Coventry et. al., 2002) have been tried with varying levels of success. However, no single method gave the desired level of white rot control. Fungicides are among the most effective options for white rot management. Avila De Moreno (1991) found that vinclozolin and carbendazim applied 45 and 75 days after sowing gave the best control of the disease. Earlier, it has been also reported that vinclozolin and iprodione (Utkhede and Rahe, 1979), and procymidone (Stewart and Fullerton, 1991; Fullerton et. al., 1995) gave reduction of disease incidence up to $75-95 \%$ when applied as seed and soil treatments. Melero-Varaet.al. (2000) found that tebuconazole was effective in reducing the incidence and progress of the disease and increasing the yield when applied as a clove treatment. According to Duff et.al. (2001)procymidone and tebuconazole applied as seed treatment resulted in better crop yields. Currently public concern about the impact of pesticides, including fungicides, on human health and the environment is greater than ever before. Fungicides constitute a potential risk to humans who are exposed to them directly through various ways and indirectly through diet.

Therefore, the present study aimed at reducing or preventing the use of chemical fungicides through finding other alternative methods of nonchemical control by using secondary metabolites of some phytopathogenic fungi.

\section{MATERIALS AND METHODS}

\section{Isolation and identification of S. cepivorum}

Samples of infected onion bulbs showing the typical symptoms of white rot were collected from different locations in Dakahlia and Gharbia governorates. Two methods were used to isolate the pathogen from collected samples. The first was by picking off the mycelial growth from diseased onion bulbs and roots according to Clarksonet.al.(2002). The second method was conducted by picking off sclerotia from diseased onion bulbs and roots according to Harper and Stewart (2000) and Clarkson et.al. (2002).

\section{Production of culture filtrates}

S. cepivorum was grown on autoclaved onion potato dextrose broth (OPDB) medium. Flasks were inoculated with one disc ( $5 \mathrm{~mm}$ diameter) of $7-$ day-old culture grown on PDA and then incubated at $20 \pm 2^{\circ} \mathrm{C}$ in the dark for 30-45 days until mycelial growth covered the medium surface in the flasks to produce large numbers of sclerotia and secondary metabolites. The liquid cultures were then filtered through Whatman No.1 filter paper, centrifuged at $12000 \mathrm{rpm}$ for $30 \mathrm{~min}$., and sterilized by using membrane filter of $0.22 \mu \mathrm{m}$ 
pore size. The resulted filtrate was kept in sterilized dark bottles in a refrigerator at $5^{\circ} \mathrm{C}$ until used for further studies.

\section{Extraction of crude metabolites}

Culture filtrate was concentrated to $10 \%$ of its original volume by using a rotary evaporator at $30^{\circ} \mathrm{C}$. Filtrates were extracted three times with chloroform followed by ethyl acetate using separating funnel (using 0.3 volume of the organic solvent per volume of filtrate), and then filtered through anhydrous sodium sulfate $\left(\mathrm{Na}_{2} \mathrm{SO}_{4}\right)$. The resulting organic fractions were subjected to dryness using a rotary evaporator to remove any traces of solvents. The residues were weighed and collected in vials.

The fungal biomass (mycelium and sclerotia, of $S$. cepivorum) was air dried at room temperature to constant weight, and ground into fine powder in a high-speed micro mill. The powder was soaked and extracted with methanol at a rate of $1: 2.5(\mathrm{w} / \mathrm{v})$ for $48 \mathrm{~h}$ on a shaker, andfiltered through two layers of WhatmanNo.1 filter paper, then centrifuged at $12000 \mathrm{rpm}$ at $4^{\circ} \mathrm{C}$ for $30 \mathrm{~min}$. Solvent was removed in vacuole at $60-65^{\circ} \mathrm{C}$ to give a crude extract using a rotary evaporator. The methanol extract was preserved in a desiccator until using and serial concentrations were made up from the stock.

\section{Effect of $S$. cepivorum culture filtrate and extract fractions on the mycelial growth and sclerotia formation of $S$. cepivorum}

S. cepivorum culture filtrate was mixed with sterilized potato dextrose agar (PDA) just before pouring into 9-cm-diameter Petri dishes, to obtain concentrations of $0,10,25$ and $50 \%$. Three plates (as replicates) were made for each treatment (concentration). Plates were inoculated in the center with 5-mm-diameter discs of $S$. cepivorum from 7-day-old culture, and incubated at $20 \pm 2^{\circ} \mathrm{C}$. Colonies diameters were measured (in two diagonal dimentions) when the mycelia growth covered the surface in the control plates. Inhibition of growth was calculated in relation to the growth in the control plates according to the equation proposed by Pinto et. al. (1998).

$$
\text { Inhibition } \%=\left(1-\frac{\text { Diameterof treatedcolony }}{\text { Diameterof controlcolony }}\right) \times 100
$$

Chloroform, ethyl acetate and methanol extracts of $S$. cepivorum culture filtrate were incorporated into PDA medium to prepare three concentrations of each extract $(400,800$ and $1200 \mathrm{ppm})$. Dimethyl sulfoxide (DMSO) was added to the medium at $0.5 \mathrm{ml} / \mathrm{L}$ to enhance compound solubility. Three replicates were used for each concentration. The control treatment was made by mixing PDA with DMSO $(0.5 \mathrm{ml} / \mathrm{L})$ only. Plates were inoculated with 5-mm-diameter discs of S. cepivorum taken from 7-day-old culture. Colony diameters were measured as described earlier (De-Billerbeck et. al. (2001). The number of sclerotia was determined in each treatment 15 days after inoculation. 
Effect of $S$. cepivorum culture filtrate and extract fractions on $S$. cepivorum sclerotia germination

Sclerotia of $\boldsymbol{S}$. cepivorum were surface sterilized with $0.5 \%$ sodium hypochlorite or $70 \%$ ethyl alcohol for 5 min., then rinsed three times with sterilized distilled water, and transferred onto sterile filter paper inside a laminar flux chamber for an overnight to remove excess moisture. Sclerotia were then placed onto PDA medium amended with $S$. cepivorum culture filtrate (at $0,10,25$ and $50 \% \mathrm{v} / \mathrm{v}$ ) or organic solvent extracts (at concentrations of 400,800 and $1200 \mathrm{ppm}$ ) while DMSO was added to the medium (at $0.5 \mathrm{ml} / \mathrm{L}$ ) to enhance compound solubility For the control treatment, sclerotia were placed onto sterilized PDA amended with $0.1 \mathrm{ml}$ di$\mathrm{N}$-propyl di-sulfate containing DMSO $(0.5 \mathrm{ml} / \mathrm{L})$ and incubated at $20 \pm 2^{\circ} \mathrm{C}$. Sclerotial germination was evaluated daily when germination was $100 \%$ in the control treatment.

\section{Statistical analyses}

Statistical analyses of all data were done using the statistical software package CoStat (2005). All comparisons were first subjected to one way analysis of variance (ANOVA) and significant differences between treatment means were determined using Duncan's multiple range test at $P<0.05$ (Duncan, 1955).

\section{RESULTS}

Effect of $S$. cepivorum culture filtrate and extract fractions on the mycelial growth and sclerotia formation of $S$. cepivorum Filtrate of $S$. cepivorum cultures significantly inhibited the mycelial growth of $S$. cepivorum by $51.9 \%$ when used at a concentration of $50 \%(\mathrm{v} / \mathrm{v})($ Table 1$)$. Culture filtrate at $25 \%(\mathrm{v} / \mathrm{v})$ caused slight inhibition of fungal growth by $13 \%$ (Table 1$)$. Culture filtrate at 50 and $25 \%$ significantly inhibited sclerocial formation of the pathogen S. cepivorum by 98.6 and $94 \%$, respectively (Table 1). At all concentrations of the culture filtrate, no sclerotia germination of $S$. cepivorum was observed (Table 1).

Table 1: Antifungal activity of Sclerotium cepivorum culture filtrate against mycelial growth, sclerotial formation and sclerotia germination of Sclerotium cepivorum

\begin{tabular}{|l|c|c|c|c|c|}
\hline $\begin{array}{c}\text { Culture filtrate } \\
\text { concentration } \\
(\mathbf{v} / \mathbf{v})\end{array}$ & $\begin{array}{c}\text { Colony } \\
\text { diameter } \\
\mathbf{( c m )}\end{array}$ & $\begin{array}{c}\text { Inhibition } \\
\text { of mycelial } \\
\text { growth }(\%)\end{array}$ & $\begin{array}{c}\text { Number of } \\
\text { sclerotia }\end{array}$ & $\begin{array}{c}\text { Inhibition of } \\
\text { sclerotial } \\
\text { formation } \\
(\%)\end{array}$ & $\begin{array}{c}\text { Inhibition of } \\
\text { sclerotia } \\
\text { germination } \\
(\%)\end{array}$ \\
\hline $10 \%$ & $9.00 \mathrm{a}^{1}$ & 0 & $7.2 \times 10^{4} \mathrm{a}$ & 0 & $100 \mathrm{~b}$ \\
\hline $25 \%$ & $7.83 \mathrm{~b}$ & 13 & $4.33 \times 10^{3} \mathrm{~b}$ & 94 & $100 \mathrm{~b}$ \\
\hline $50 \%$ & $4.33 \mathrm{~b}$ & 51.9 & $1 \times 10^{3} \mathrm{~b}$ & 98.6 & $100 \mathrm{~b}$ \\
\hline $0 \%($ Control) & $9.00 \mathrm{a}$ & - & $7.2 \times 10^{4} \mathrm{a}$ & - & $16.67 \mathrm{a}$ \\
\hline
\end{tabular}

Values within a column followed by a different letter are significantly different according to Duncan'smultiple range test $(P=0.05)$ 
Effect of $S$. cepivorum culture filtrate and extract fractions on $S$. cepivorum sclerotia germination

Methanol extract induced the highest reduction in the fungal growth (93.33 and $93.56 \%$ ) when used at concentrations of 800 and $1200 \mathrm{ppm}$, respectively (Table 2). Ethyl acetate extract was the second most effective growth inhibitor when used at those concentrations, reducing the fungal growth by 88.89 and $90.56 \%$, respectively. Chloroform extract was the least effective growth inhibitor in all of its concentration tested (Table 2; Fig. 1, 2). All extracts completely suppressed the formation and germination of sclerotia at all concentrations.

Table 2: Antifungal activity of organic solvent extracts on mycelial growth of Sclerotium cepivorum

\begin{tabular}{|l|c|c|c|c|c|c|}
\hline \multirow{2}{*}{ Treatment } & \multicolumn{2}{|c|}{$\mathbf{4 0 0} \mathbf{~ p p m}$} & \multicolumn{2}{c|}{$\mathbf{8 0 0}$ ppm } & \multicolumn{2}{c|}{$\mathbf{1 2 0 0}$ ppm } \\
\cline { 2 - 7 } & $\begin{array}{c}\text { Colony } \\
\text { diameter } \\
\text { (cm) }\end{array}$ & $\begin{array}{c}\text { Inhibition } \\
\text { of mycelial } \\
\text { growth (\%) }\end{array}$ & $\begin{array}{c}\text { Colony } \\
\text { diameter } \\
\text { (cm) }\end{array}$ & $\begin{array}{c}\text { Inhibition } \\
\text { of mycelial } \\
\text { growth (\%) }\end{array}$ & $\begin{array}{c}\text { Colony } \\
\text { diameter } \\
\text { (cm) }\end{array}$ & $\begin{array}{c}\text { Inhibition } \\
\text { of mycelial } \\
\text { growth (\%) }\end{array}$ \\
\hline $\begin{array}{l}\text { Chloroform } \\
\text { extract }\end{array}$ & $6.6 \mathrm{~b}^{1}$ & 26.67 & $2.6 \mathrm{~b}$ & 71.11 & $2.6 \mathrm{~b}$ & 71.11 \\
\hline $\begin{array}{l}\text { Ethyl acetate } \\
\text { extract }\end{array}$ & $1.3 \mathrm{~d}$ & 85.56 & $1 \mathrm{c}$ & 88.89 & $0.85 \mathrm{c}$ & 90.56 \\
\hline $\begin{array}{l}\text { Methanol extract } \\
\text { Control with } \\
\text { DMSO }\end{array}$ & $1.6 \mathrm{c}$ & 82.22 & $0.6 \mathrm{~d}$ & 93.33 & $0.58 \mathrm{~d}$ & 93.56 \\
\hline $\begin{array}{l}\text { Control without } \\
\text { DMSO }\end{array}$ & $9 \mathrm{a}$ & 0 & $9 \mathrm{a}$ & 0 & $9 \mathrm{a}$ & 0 \\
\hline
\end{tabular}

Values within a column followed by a different letter are significantly different according to Duncan's multiple range test $(P=0.05)$

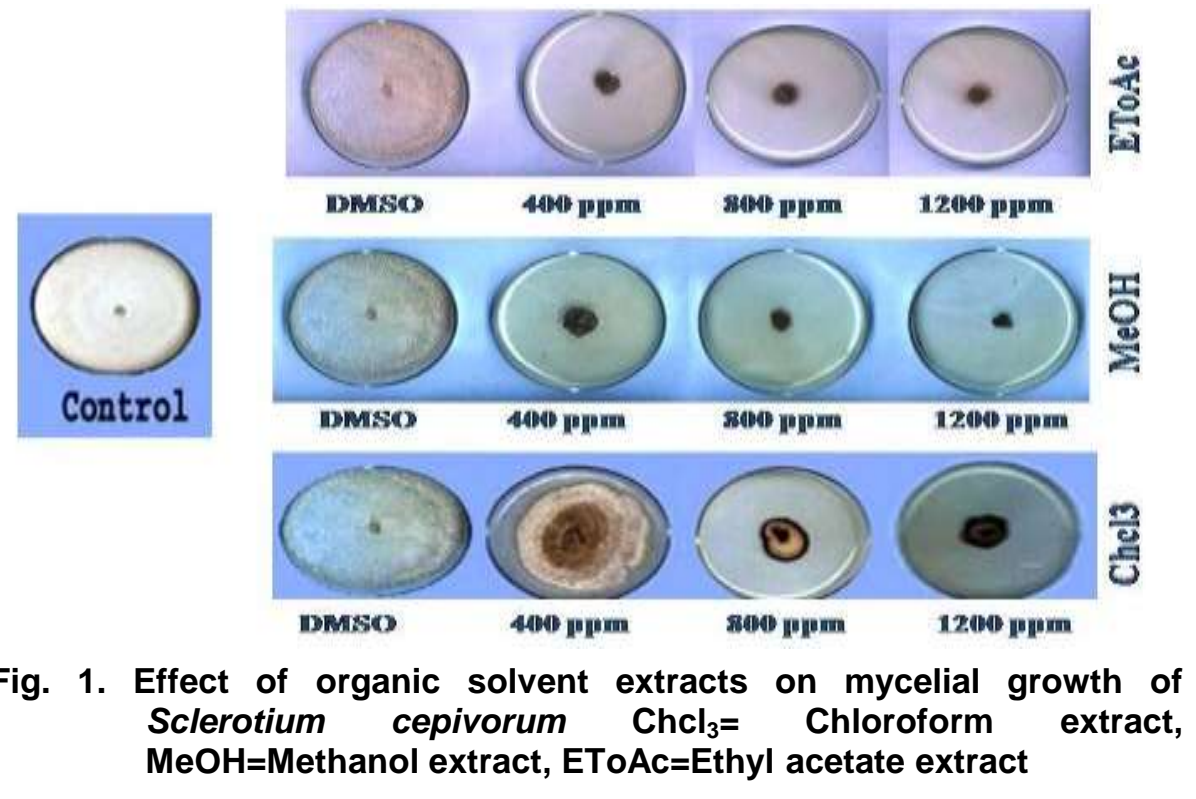


Fig. 2. Effect of organic solvent extracts on mycelial growth of Sclerotium cepivorum (mean \pm s.e) at concentrations of 400 , 800 and 1200 ppm .

\section{DISCUSSION}

The secondary metabolites have been classified in different groups based on their biosynthetic origin or their chemical structure and they include non-volatile (e.g. peptaibols) and volatile compounds (e.g. simple aromatic metabolites, terpenes, isocyano metabolites, polyketides, butenolides, pyrones, and linoleic acid) (Cardoza et. al., 2005; Reino et. al., 2008; Serrano-Carreon et. al., 1993). Secondary metabolites which defuse in the agar media and stop the other fungi to grow without any of hyphal contact able to inhibit the growth of the pathogenic fungi (Cooney and Lauren, 1999; Rubioet. al., 2008).

Literature on the role of culture filtrates of $S$. cepivorum and organic solvent extracts of this fungus as a source of fungitoxic chemicals and its importance in controlling different plant pathogens are not found. Furthermore, most of the scientific literature on culture filtrates of fungi as natural phytotoxins focuses on phytotoxicity of the culture filtrates to some plants or weeds and relationship to disease symptomology and their toxins proposed as potential natural herbicides. There are many reasons why natural products might be good sources of molecules or molecular templates for pesticides or at least lead to new targets of action (Rimando and Duke 2006).

Methanol extract was the most effective extract in inhibiting the mycelial growth of the fungus. These findings are supported, in part, with many researchers (Sharad Verma, 2010; Neyceeet. al., 2012). The inhibition of formation and germination of sclerotia this results may be due to 
accumulation in the membrane bilayer and filed of compose phospholipids and sterol composition of $S$. cepivorum as well as lipid peroxidation of mycelia and sclerotia development (Luciniet. al., 2006). Ethyl acetate extract gave high reduction on the mycelial growth and suppressed the formation of sclerotia, this finding agrees with Jaideep et. al., 2012.

\section{REFERENCES}

Abd-El-Razik, A.A., Shatla, M.N., Rushidi, M., 1973. Studies on the infection of onion plants by SclerotiumcepivorumBerk. Phytopathol 76, 108-116.

Andrea, T.B., Emma, Z.M., Carmen, G.C., Ronald, F.C., 1996. The use of arbuscularmycorrhizae to control onion white rot (SclerotiumcepivorumBerk) under field conditions. Mycorrhizae 6, 253257.

Avila De Moreno, C., 1991. Chemical control of SclerotiumcepivorumBerk. causing white rot of garlic. Fitopatol. Colombiana 15, 62-69.

Banks, E.andEdgington, L.V., 1989. Effect of integrated control practices on the onion white rot pathogen in organic soil. Can. J. Plant Pathol. 11, 268-272.

Cardoza, R.E.; Hermosa, M.R.; Vizcaino, J.A.; Sanz, L.; Monte, E. and Gutierrez, S. (2005). Secondary metabolites produced by Trichoderma and their importance in the biocontrol process. In: Mellado, E., Barredo, J.L. (Eds.), Microorganisms for Industrial Enzymes and Biocontrol. Research Signpost, Kerala, pp. 1-22.

Clarkson, J. P.; T. Payne; A. Mead and J. M. Whipps. (2002). Selection of fungal biological control agents of Sclerotiumcepivorum for control of white rot by sclerotial degradation in a UK soil. Plant Pathology 51 (6), 735-745.

Coley-Smith, J.R. and Parfitt, D., 1986. Some effects of diallyldisulphide on sclerotia of Sclerotiumcepivorum and possible novel control method for white rot disease of onions. Pesticide Sci. 37, 587-594.

Coley-Smith, J.R., Parfitt, D. and Taylor, I.M., 1987. Studies of dormancy in sclerotia of SclerotiumcepivorumBerk. Plant Pathol. 36, 594-599.

Cooney, J.M. and Lauren, D.R. (1999). Biotransformation of the Trichoderma metabolite 6- n-pentyl-2H-pyran-2-one (6PAP) by selected fungal isolates. J. Nat. Prod. 62, 681-683.

CoStat program, Version 6.311 (2005). CoHort Software, 798 Lighthouse Ave. PMB 320, Monterey, CA, 3940, USA. (http://www.cohort.com).

Coventry, E., Noble, R., Mead, A. and Whipps, J.M., 2002. Control of white rot (Sclerotiumcepivorum) with composted onion waste. Soil Biochem. 34, 1037-1045.

Crowe, F.J., Hall, D.H., Greathead, A.S., Baghott, K.G., 1980. Inoculums density of Sclerotiumcepivorum and the incidence of white rot of onion and garlic. Phytopathology 70, 64-69. 
Duff, A.A., Jackson, K.J. and O'Donnell, W.E., 2001. Tebuconazolee (folicur) potential in the control of white rot (Sclerotiumcepivorum) in garlic in subtropical Queensland, Australia, Second International Symposium on edible Alliaceae. ActaHorticult. 555, 247-250.

Duncan, D. (1955). Multiply range and multiple $\mathrm{F}$ test. Biometrics 11 , $1-42$.

Entwistle, A.R., 1986. Differences in the incidence of Allium white rot in direct drilled and module-grew bulb onions. In: Entwistle, A.R. (Eds.), Proceedings of the third international workshop on Allium white rot, Wellesbourne, UK, pp. 1-5.

Entwistle, A.R., 1990a. Allium white rot and its control. Soil Use Manage. 6, 201-209.

Entwistle, A.R., 1990b. Measuring net changes in populations of Sclerotiumcepivorumsclerotia to evaluate the long term potential of control measures. In: Entwistle, A.R., Mattusch, P. (Eds.). Proceedings of fourth international workshop on Allium white rot. Neustdat/Weinstrasse, Federal Republic of Germany. pp: 59-68.

Fullerton, R.A. and Stewart, A., 1991. Chemical control of onion white rot (SclerotiumcepivorumBerk) in the Pukekohe district of New Zealand. NZ J. Crop Horticult. Sci. 19, 121-127.

Fullerton, R.A., Stewart, A. and Slade, E.A., 1995. Use of demethylation inhibiting fungicides (DMls) for the control of onion white rot (SclerotiumcepivorumBerk.) in the New Zealand. NZ J. Crop Horticult. Sci. 23, 121-125.

Gerlagh, M., Whipps, J.M., Budge, S.P. and Goossen-van De Geijn, H.M., 1996. Efficacy of isolates of Coniothyriumminitans as mycoparasites of Sclerotiumcepivorum, and Botrytiscinerea on tomato stem pieces. Eur. J. Plant Pathol. 102, 787-793.

Harper G. E. and A. Stewart (2000) Magnetic separation technique for the isolation of sclerotiumcepivorum from iron-rich soil particles. Soil Biology and Biochemistry 32:135-137.

Harrison, Y.A. and Stewart, A., 1988. Selection of fungal antagonists for biological control of onion white rot in New Zealand. NZ J. Exp. Agri. 16, 249-256.

Jaideepsingh, Sunder Singh, TejPratap and Vivek k. Arya (2012) Phytochemical analysis and Antifungal Activity of ethyl acetate extract of AndrographisPaniculata.Asian Journal of Pharmacy and Medical Science. Vol 2 (3), 2012.

Kay, S.J.and Stewart, A., 1994b. The effect of fungicides on fungal antagonists of onion white rot and selection of dicarboximide-resistant biotypes. Plant Pathol. 43, 863-871.

Lucini E. I., M. P. Zunino, M. L. López and J. A. Zygadlo (2006) Effect of Monoterpenes on Lipid Composition and Sclerotial Development of SclerotiumcepivorumBerk. Journal of Phytopathology Volume 154, Issue 7-8 pages 441-446, August 2006.

Melero-Vara, J.M., Parados-Ligero, A.M. and Basallote, U.M.S., 2000. Comparison of physical and chemical and biological methods of controlling garlic white rot. Eur. J. Plant Pathol. 166, 581-588. 
Mengistu, H. and Seid, A., 1993. Outbreak of garlic bulb rots in Ethiopia. Annual report. DebreZeit Agricultural Research Center: Alemaya University of Agriculture 124pp.

Mengistu, H., 1994. Research on vegetables disease in Ethiopia. In: Herath, E., Dessalegne, L. (Eds.), Proceedings of the Second National Horticultural Workshop of Ethiopia, 1-3 December. IAR, Addis Ababa, Ethiopia, pp. 209-215.

Neycee M. A., GH.A. Nematzadeh, A. Dehestani and M. Alavi (2012)Assessment of antifungal effects of shot extracts in chinaberry (Meliaazedarach) against 5 phytopathogenic fungi.Intl. J. Agron. Plant. Prod. Vol., 3 (9), 313-317, 2012.

Perez, M.L., Salinas, G.J. and Redondo, J.E., 1994. Main disease on Allium species in Mexico with emphasis on white rot (SclerotiumcepivorumBerk.). In: Entwistle A.R., Melero-Vara J.M., (Eds), Proceedings of the Fifth International Workshop on Allium white rot, pp: 6-11.

Pinto, C.M.F., Mafia, L.A., Casali, V.W.D., Berger, R.D. and Mizubuti, E.S.G., 1998. Progress of white rot on garlic cultivars planted at different times. Plant Dis. 82, 1142-1146.

Porter, I.J. and Merriman, P.R., 1983. Effects of solarization of soil on nematode and fungal pathogens at two sites in Victoria. Soil Boil. Biochem. 15, 39-44.

Reino, J. L.; Guerrero, R. F.; Hernández-Galan, R. and Collado, I. G. (2008). Secondary metabolites from species of the biocontrol agent Trichoderma. Phytochem. Rev.7, 89-123.

Rimando A. M. and Duke S. O. (2006). Natural products for pest management In: Rimando A. and Duke S. (Eds.), Natural Products for Pest Management. ACS Press, Washington DC, pp. 2-21.

Rubio, M. B.; Hermosa, R.; Reino, J. L.; Collado, G. and Monte, E. (2008). Thctf1 transcription factor of Trichodermaharzianum is involved in 6pentyl-2H-pyran-2-one production and antifungal activity. Fungal Genetics and Biology. doi:10.1016/j.fgb.2008.10.008.

Serrano-Carreon, L.; Hathout, Y.; Bensoussan, M. and Belin, J. M. (1993). Metabolism of linoleic acid or mevalonate and 6-pentyl-alpha-pyrone biosynthesis by Trichoderma species. Appl. Environ. Microbial. 59, 2945-2950.

SharadVerma (2010) Screening of Streptomyces sp. MTCC4 for the production of antifungal compound against Sclerotiumrolfsii. J Biochem Tech (2010) 2(4):199-202. ISSN: 0974-2328.

Stewart, A. and Fullerton, R.A., 1991. Additional studies on the control of onion white rot (SclerotiumcepivorumBerk) in New Zealand. NZ J. Crop Horticult. Sci. 19, 129-134.

Utkhede, R.S. and Rahe, J.E., 1979. Evaluation of chemical fungicides for the control of onion white rot. Pesticide Sci. 10, 414-418. 
تقييم مبدئي علي النـواتج الثانويـة للفطر Sclerotiumcepivorum المسبب الفيب

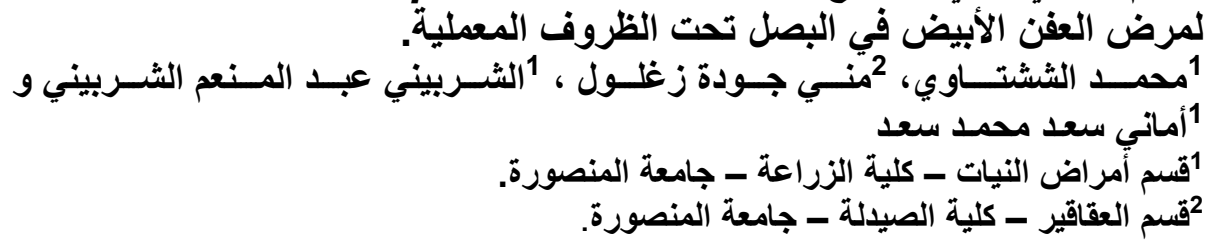

استخدمت طريقتين للحصول علي النواتج الايضية للفطر Sclerotiumcepivorum.

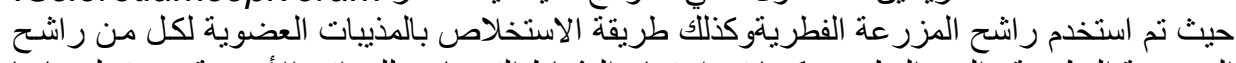

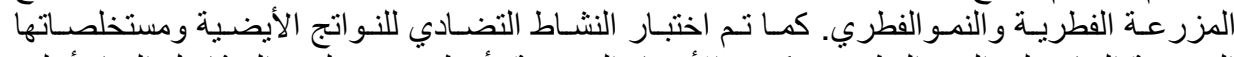

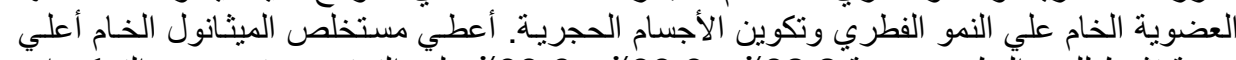

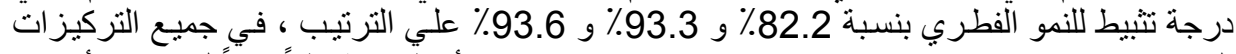

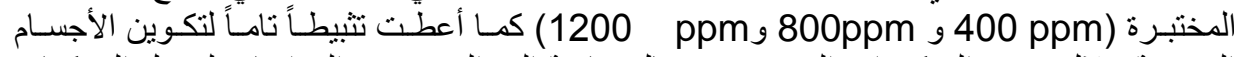

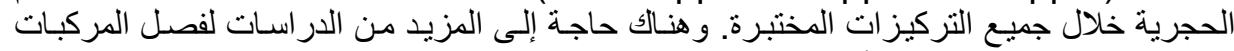
الفعالة من مستخلص النواتج الأيضية للفطر الترك ولن

كلية الزراعة - جامعة المنصورة كلية الزراعة - جامعة كفر الثيخ

$$
\text { قام بتحكيم البحث }
$$

أ.ـد / ياسر محمد نور الدين شبانه أ.د / محمود محمد بدر 